\title{
Effects of Peri-Urban Land Use Changes on Forest Ecosystem Services: The Case of Settlements Surrounding Pugu and Kazimzumbwi Forest Reserves in Tanzania
}

\author{
John M. Lupala ${ }^{1}$, Makarius V. Mdemu ${ }^{1}$ \& Stanslaus P. Butungo ${ }^{1}$ \\ ${ }^{1}$ School of Urban and Regional Planning, Ardhi University, Tanzania \\ Correspondence: John M. Lupala, School of Urban and Regional Planning, Ardhi University, Tanzania. E-mail: \\ lupalajohn@yahoo.com
}

Received: October 23, 2014

Accepted: November 13, 2014 Online Published: November 28, 2014

doi:10.5539/jgg.v6n4p231

URL: http://dx.doi.org/10.5539/jgg.v6n4p231

\begin{abstract}
Peri-urban settlements constitute foci of urban expansion in most cities of the developing world. They provide livelihood opportunities by exploiting adjacent resources such as forest products, land and water. Yet they constitute a conflicting zone of development whereby urban and rural livelihoods compete for space. This paper examines the effects of peri-urban land-use changes on forest ecosystem services from Pugu and Kazimzumbwi forest reserves. Land use changes were analysed using series aerial photographs of between 1975 and 2012. This was complemented with participatory resource mapping, focus group discussion and key informant interviews to identify and qualify changes in ecosystem services over the period of 37 years. Literature review was also used to capture non-spatial data. Results indicate that there has been tremendous change in built-up area surrounding the forest reserve. It increased from 608.78 hectares in 1975 to 4,933.51 hectares in 2012 representing an increase from 2.4 to 19.1 percent. The same trend pervaded residential and the reverse for open land uses. These changes have resulted into disappearance of ecosystem services (plant and animal species, honey and wax production, mushrooms and water resources). The remaining forest ecosystem services are likely to completely disappear in few years if protection and conservation measures will not be stepped up. Guided land use plans for all areas surrounding the forest reserves and decentralized forest management have been recommended to facilitate restoration of forest services.
\end{abstract}

Keywords: peri-urban, land use changes, ecosystem services, deforestation, forest degradation

\section{Introduction}

The impact of land use changes on the forest ecosystem services may have profound negative impacts on forest ecosystems which provide services to support human life. Land use changes are mainly influenced by change in demography, policies, economical and political factors or sometimes a combination of these factors (Lambin, Geist and Lepers, 2003). In Tanzania, the villagization programme that was implemented in early 1970s forced people to move from scattered homesteads to nucleated village settlements. In the peri-urban areas of large urban centres like Dar es Salaam, this programme resulted into clearance of forests and significant change in land uses (Burgess and Dickinson, 1993). In the urban context, demographic changes particularly rural-urban and intra-city migrations contributed to rapid land use changes (Briggs and Mwamfupe, 2000). Another key driver of rapid land use changes include the escalating demand for residential land triggered by rapid population growth (Lupala, 2002; Kironde, 2000). Dramatic movement of people to peri urban areas such as Pugu in the early 1980s was due to cheapness of land where the poor could afford to buy land, erect shelter and conduct agricultural activities (Briggs and Mwamfupe, 2000; Malugu, 2007).

The relationship that exists between forests and urban land uses is always in conflicts where urban land uses tend to expand at the expense of diminishing forests and associated ecosystem services. Due to lack of measures to balance between forests conservation and urban land use expansion, sustainability for forests and ecosystem services are increasingly being compromised. Recent research conducted in Pugu and Kazimzumbwi to determine the rate of forest cover change reveal that for the periods 1980-1995 and 1995-2010, closed forest in Pugu Forest Reserve decreased by 4.5 and 25.3 percents respectively, while for Kazimzumbwi Forest reserve, closed forest decreased by 11.9 and 31.3 percents respectively (Kashaigili et al., 2013). At the same time, Monga and Gwegime (2011) projected complete deforestation of Pugu and Kazimzumbwi forest by 2017 if measures for 
protecting the forests are not implemented. Peri urban communities surrounding the two forest reserves depend on forest ecosystem services such as building materials, fuel, food, water and traditional medicines (Douglas, 2006). Therefore loss of these forest ecosystem services jeopardizes livelihood opportunities of over 86 percent of the people who depend on these forest ecosystem services (CARE-Tanzania, 2001; Frontier Tanzania, 2004). The main objective of this research was to assess the effects of peri-urban land-use changes on forest ecosystem services for Pugu and Kazimzumbwi.

\section{Location and Description of the Study Area}

The area where this study was conducted covers about 33,746.86 hectares and lies across the boundaries of Dar es Salaam and Coast regions between $38.7^{\circ}$ and $39^{\circ}$ East; and between $6.5^{\circ}$ and $7^{0}$ South (Figure 1). There are four settlements from Dar es Salaam and four in Kisarawe District that surround the forests. Those in Dar es Salaam include Pugu, Buyuni Majohe and Chanika. Statistics show the total population in these four settlements was 46,373 people constituting 70.6 of all people in the study areas. The annual average growth rate was recorded to be 3.2 percent. Those in Kisarawe include; Kazimzumbwi, Kisanga, Maguruwe and Kisarawe town with a total population of 19,311 people (29.4 percent) and annual average population growth of 2.1 percent (URT, 2013). In total there were 65,684 people living in the study area. The indigenous ethnic group is the Zaramo who accounted for about 36.7 percent of the total population and others constituted migrants.

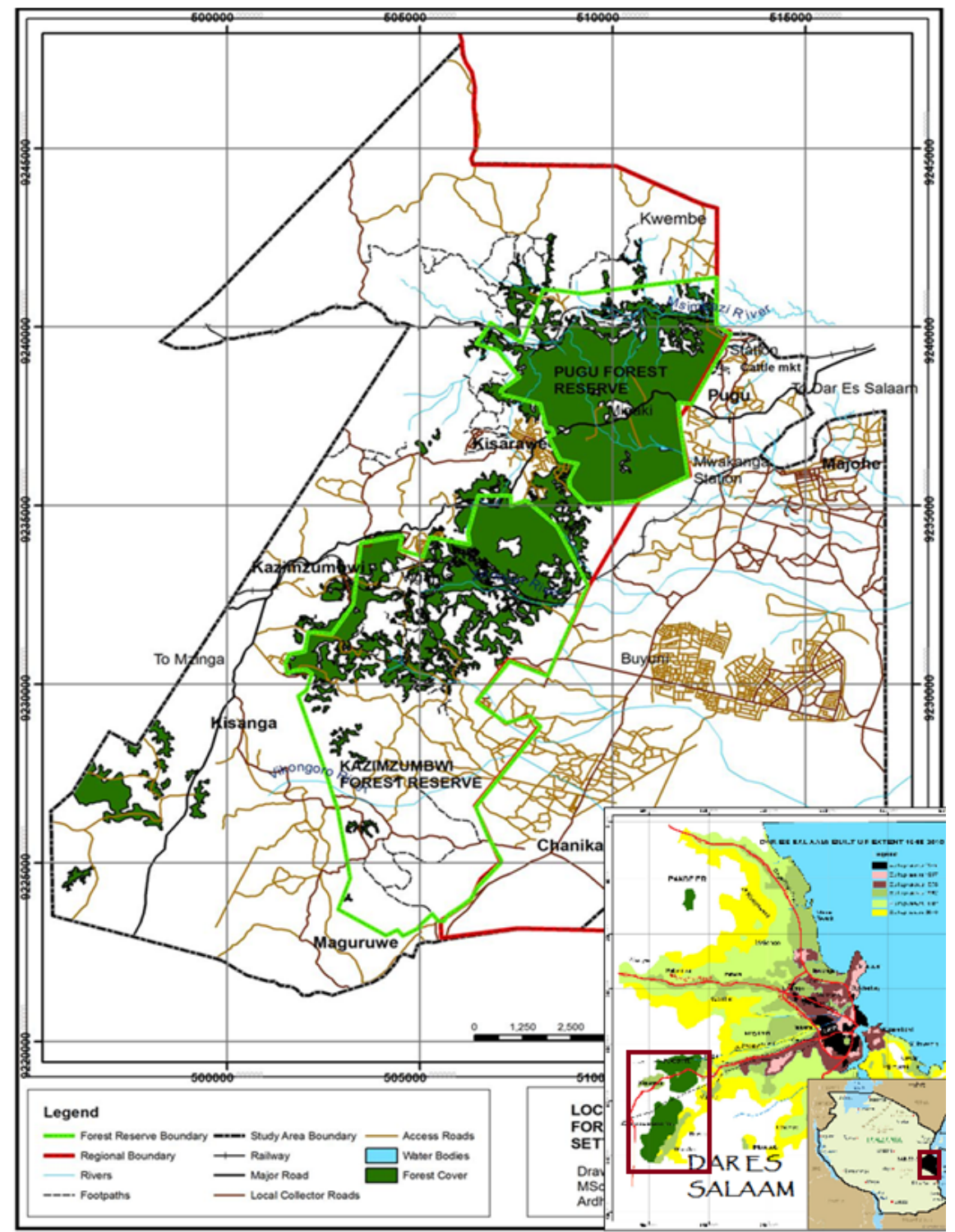

Figure 1. Location of the study areas 


\section{Methodology}

The aerial photographs for 1975, 1980, 1995, 2010 and 2012 analysed by Butungo (2013) were used as inputs for developing land use and land use changes of this study. The land uses for each epoch of land cover were confirmed by representatives of four communities surrounding the forest reserves. Ten members from each of the four communities were selected and involved in the land use identification exercise. The age categories of the members were in the range $>60>20$ years. Preliminary land use maps were produced for each epoch and used for ground-truthing and rectification of land use categories. The land use category boundaries were defined based on the boundaries of land cover classes. The identified land uses included agriculture, grazing and open land, built up area, residential and agricultural area and infrastructure land uses. The area of each land use category for each epoch was determined using Arc GIS. Determined land use areas were used to quantify land use change between the epochs of analysis. Secondary data sources such as the National Census Reports (1967-2012) were used to capture information on population growth trends in the study areas. Resource mapping and secondary data were used to identify and quantify the types and trends of forest ecosystem services over the period of 37 years from 1975 to 2012. Identified ecosystem services focused on supporting and provisioning services such as plant and animal species, honey and wax production, mushrooms and water resources. Results from land use changes analysis in periods 1975-1980, 1980-1995, 1995-2010 and 2010-2012 were compared with the results on changes in ecosystem services during the same periods in order to determine the effects of peri-urban land use changes on forest ecosystem services.

\section{Results}

\subsection{Trends in Population Increase in the Study Area}

Statistics show that with population growth rate of 3.2 percent for Dar es Salaam (Chanika and Pugu), the two settlements were experiencing relatively higher growth since 1967 as compared to those in Kisarawe. Settlements in Kisarawe had lower growth rate of 1.8 percent (see Table 3.4). Population for Chanika settlement for example leapfrogged from 917 people in 1967 to 35,726 in 2012. This growth represents 39 times increase compared to the initial population recorded in 1967. The same trend is noted for Pugu whose population increased from 1206 in 1967 to 22,322 in 2012 (Figure 2) (URT: 1967-2002). The implication of rapid population increase has been linked to rapid expansion of residential land use and encroachment of nearby forest reserves with significant effects on the ecosystem services.

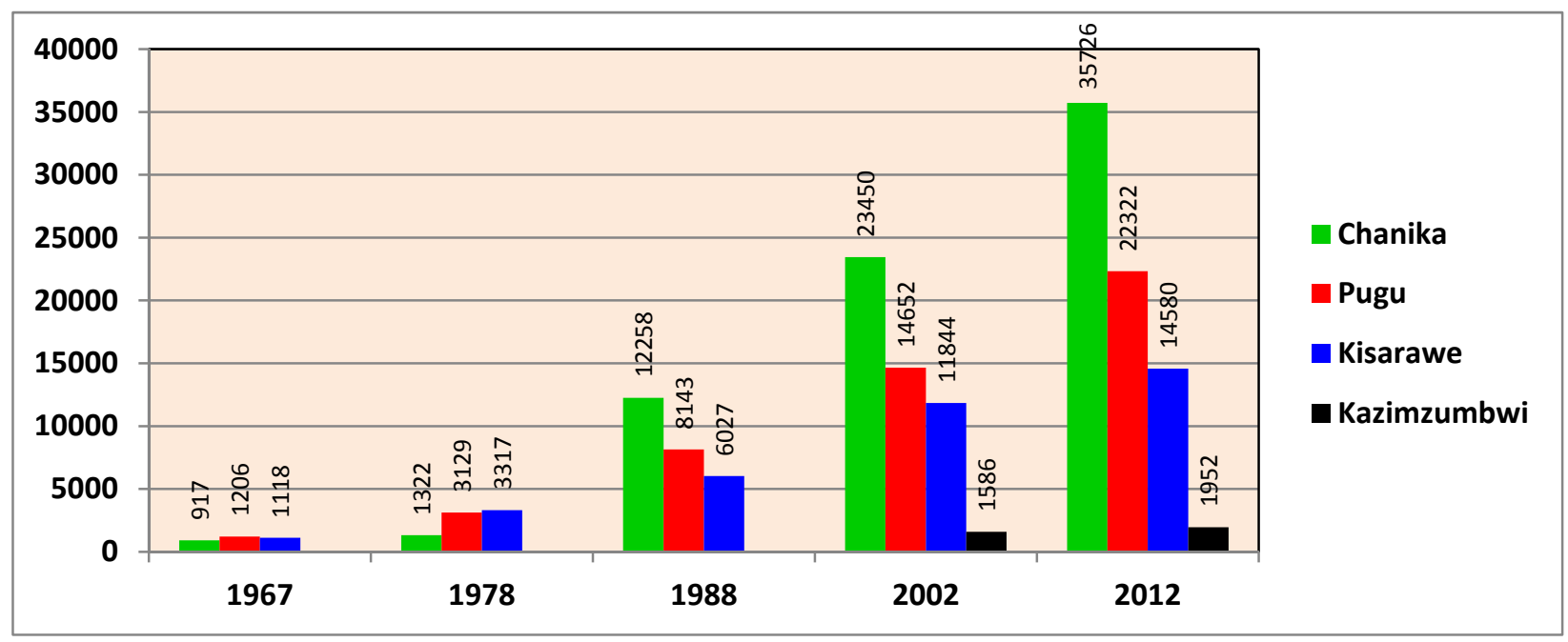

Figure 2. Population growth trends (1967-2012)

\subsection{Land Use Changes}

Analysis of land uses changes for the years of 1975, 1980, 1995, 2010 and 2012 indicate that there have been tremendous changes particularly in the built-up area increasing from 608.78 hectares in 1975 to 4933.51 hectares in 2012. In terms of percentage increase, this growth increased from 2.4 to 19.1 percent within the same period respectively. Another significant change is notable on the category of residential and agricultural land that 
increased from 989.51 to $6,893.71$ hectares within the same period. This represents a proportional increase from 3.8 to 26.7 percent. Another significant change is notable on the grazing and open land that revealed tremendous decreasing trends. It diminished from 21,716.68 hectares representing 84.1 percent to 10,251.22 hectares or 39.7 per cent of the total area over the same period of time (Figures 3, 4, 56 and Tables 1 and 2).

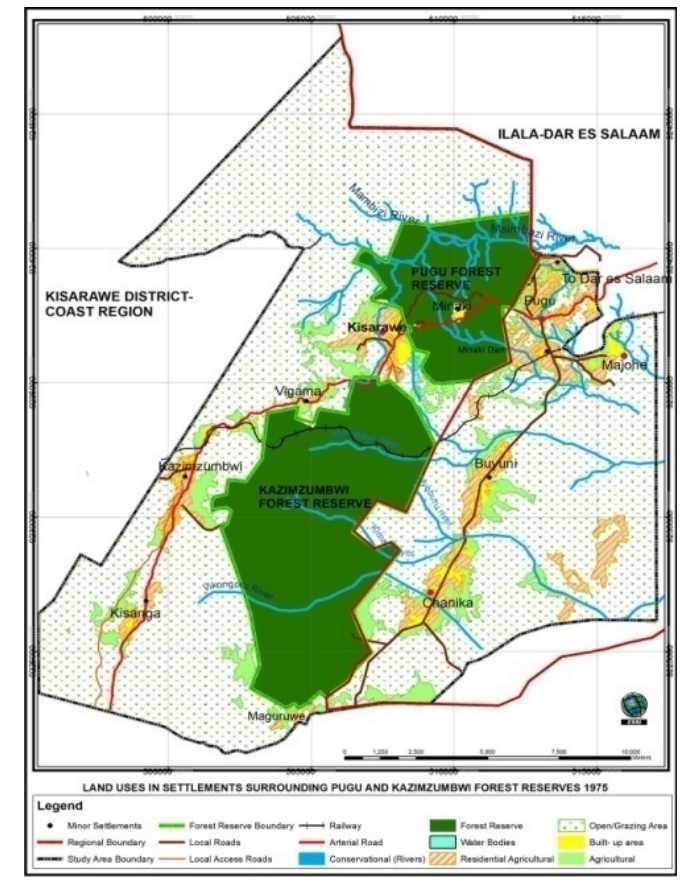

Figure 3. Land uses for areas surrounding Pugu and Kazimzumbwi Forests (1975)

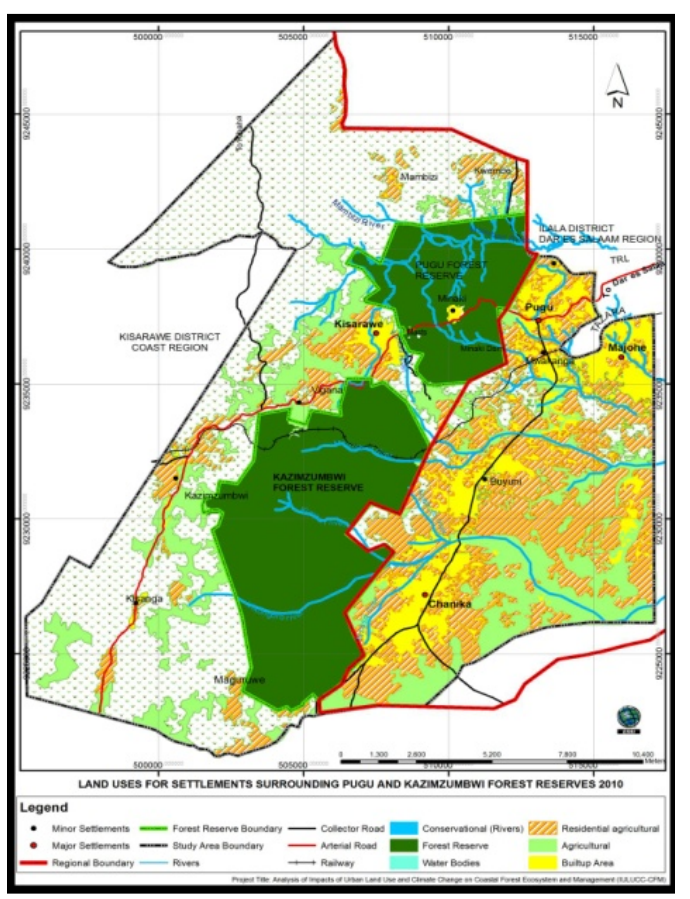

Figure 5. Land uses for areas surrounding Pugu and Kazimzumbwi Forests (1995)

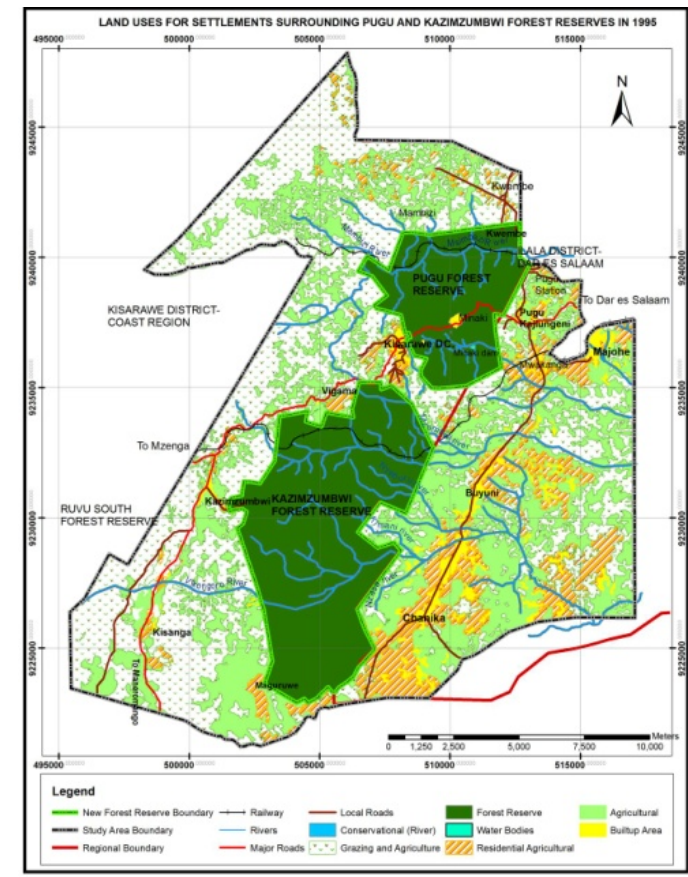

Figure 4. Land uses for areas surrounding Pugu and Kazimzumbwi Forests (1980)

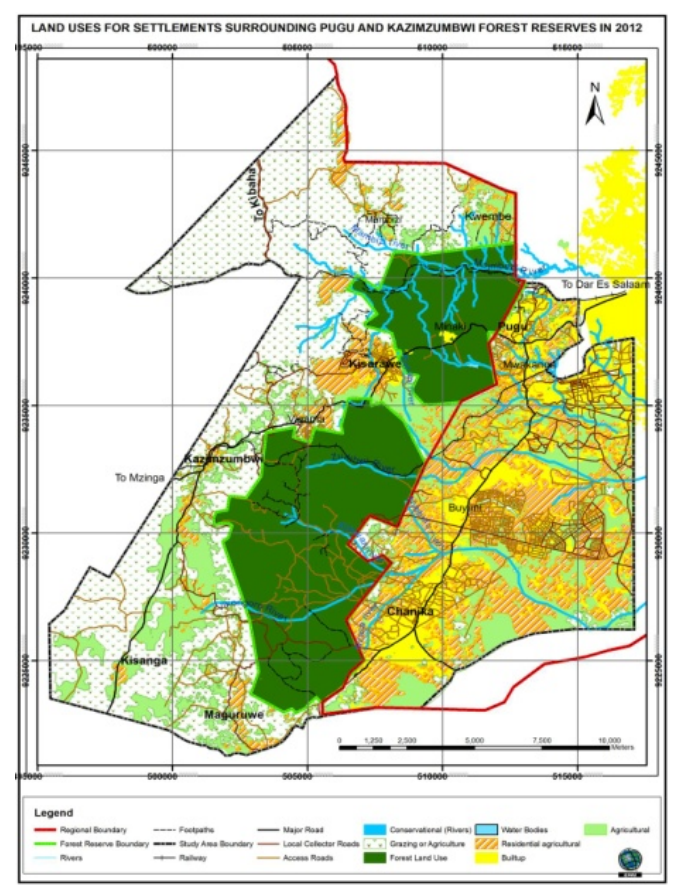

Figure 6. Land uses for areas surrounding Pugu and Kazimzumbwi Forest (2012) 
Table 1. Land use changes (1975-2012)

\begin{tabular}{|c|c|c|c|c|c|c|c|c|c|c|}
\hline \multirow[t]{2}{*}{ Land Use } & \multicolumn{2}{|l|}{1975} & \multicolumn{2}{|l|}{1980} & \multicolumn{2}{|l|}{1995} & \multicolumn{2}{|l|}{2010} & \multicolumn{2}{|l|}{2012} \\
\hline & $\begin{array}{l}\text { Land use } \\
\text { area (ha) }\end{array}$ & $\begin{array}{l}\% \text { of } \\
\text { total } \\
\text { area }\end{array}$ & $\begin{array}{l}\text { Land use } \\
\text { area (ha) }\end{array}$ & $\begin{array}{l}\% \text { of } \\
\text { total } \\
\text { area }\end{array}$ & $\begin{array}{l}\text { Land use } \\
\text { area (ha) }\end{array}$ & $\begin{array}{l}\% \text { of } \\
\text { total } \\
\text { area }\end{array}$ & $\begin{array}{l}\text { Land use } \\
\text { area (ha) }\end{array}$ & $\begin{array}{l}\% \text { of } \\
\text { total } \\
\text { area }\end{array}$ & $\begin{array}{l}\text { Land use } \\
\text { area (ha) }\end{array}$ & $\begin{array}{l}\% \text { of } \\
\text { total } \\
\text { area }\end{array}$ \\
\hline Agriculture & $2,499.27$ & 9.7 & $5,219.19$ & 20.2 & $6,418.24$ & 24.9 & $5,214.52$ & 20.2 & $3,696.54$ & 14.3 \\
\hline Grazing and open land & $21,716.68$ & 84.1 & $\begin{array}{l}18,319.5 \\
1\end{array}$ & 70.9 & $15,479.84$ & 59.9 & $10,557.51$ & 40.9 & $10,251.22$ & 39.7 \\
\hline Built up area & 608.78 & 2.4 & 689.78 & 2.7 & $1,573.85$ & 6.1 & $3,970.01$ & 15.4 & $4,933.51$ & 19.1 \\
\hline $\begin{array}{ll}\text { Residential } & \text { and } \\
\text { agricultural } & \end{array}$ & 989.51 & 3.8 & $1,582.16$ & 6.1 & $2,327.15$ & 9.0 & $6,042.28$ & 23.4 & $6,893.71$ & 26.7 \\
\hline $\begin{array}{l}\text { Infrastructure(roads/ } \\
\text { Rail) }\end{array}$ & 9.08 & 0.0 & 12.69 & 0.0 & 24.17 & 0.1 & 39.01 & 0.2 & 48.35 & 0.2 \\
\hline TOTAL & $25,823.3$ & 100.0 & $25,823.3$ & $\begin{array}{l}100 . \\
0\end{array}$ & $25,823.3$ & 100.0 & $25,823.3$ & 100.0 & $25,823.3$ & 100.0 \\
\hline
\end{tabular}

Table 2. Area and percentage change (1975-2012)

\begin{tabular}{|c|c|c|c|c|c|c|c|c|c|c|c|c|}
\hline \multirow[t]{2}{*}{ Land Use } & \multicolumn{3}{|c|}{$1975-1980$} & \multicolumn{3}{|c|}{ 1980-1995 } & \multicolumn{3}{|c|}{$1995-2010$} & \multicolumn{3}{|c|}{ 2010-2012 } \\
\hline & $\begin{array}{l}\text { Land } \\
\text { use } \\
\text { change } \\
\text { (ha) }\end{array}$ & $\begin{array}{l}\% \\
\text { change }\end{array}$ & $\begin{array}{l}\text { Land } \\
\text { use } \\
\text { change } \\
\text { (ha/yr) }\end{array}$ & $\begin{array}{l}\text { Area } \\
\text { change } \\
\text { (ha) }\end{array}$ & $\begin{array}{l}\% \\
\text { chang } \\
\text { e }\end{array}$ & $\begin{array}{l}\text { Land } \\
\text { use } \\
\text { change } \\
\text { (ha/yr) }\end{array}$ & $\begin{array}{l}\text { Area } \\
\text { change } \\
\text { (ha) }\end{array}$ & $\begin{array}{l}\% \\
\text { cha } \\
\text { nge }\end{array}$ & $\begin{array}{l}\text { Land } \\
\text { use } \\
\text { change } \\
\text { (ha/yr) }\end{array}$ & $\begin{array}{l}\text { Area } \\
\text { change } \\
\text { (ha) }\end{array}$ & $\begin{array}{l}\text { \% } \\
\text { chan } \\
\text { ge }\end{array}$ & $\begin{array}{l}\text { Land } \\
\text { use } \\
\text { change } \\
\text { (ha/yr) }\end{array}$ \\
\hline Agriculture & 2719.92 & 109 & 543.98 & 1199.05 & 23 & 79.94 & $\begin{array}{l}-1203.7 \\
2\end{array}$ & -19 & -80.25 & -1517.9 & -29 & $\begin{array}{l}-505.9 \\
9\end{array}$ \\
\hline $\begin{array}{l}\text { Grazing and } \\
\text { open land }\end{array}$ & -1422.2 & -7 & $\begin{array}{l}-284.4 \\
3\end{array}$ & -2839.7 & -16 & $\begin{array}{l}-189.3 \\
1\end{array}$ & $\begin{array}{l}-4922.5 \\
0\end{array}$ & -32 & $\begin{array}{l}-328.1 \\
7\end{array}$ & -306.30 & -3 & $\begin{array}{l}-102.0 \\
9\end{array}$ \\
\hline Built up area & 81.00 & 13 & 16.20 & 884.07 & 128 & 58.94 & $\begin{array}{l}2396.1 \\
6\end{array}$ & 152 & 159.74 & 963.5 & 24 & 321.17 \\
\hline $\begin{array}{l}\text { Residential } \\
\text { agricultural }\end{array}$ & 592.65 & 60 & 118.53 & $1,044.99$ & 47 & 49.67 & $\begin{array}{l}3715.1 \\
3\end{array}$ & 160 & 247.68 & 851.43 & 14 & 283.81 \\
\hline $\begin{array}{l}\text { Infrastructur } \\
\text { e (Roads, } \\
\text { Rail) }\end{array}$ & 3.61 & 40 & 0.72 & 11.48 & 91 & 0.77 & 14.84 & 61 & 0.99 & 9.34 & 24 & 3.11 \\
\hline
\end{tabular}

However, when the two regions were compared, settlements in Dar es Salaam (Chanika and Pugu) were changing more rapidly in terms of land uses and built up areas as compared to those of Kisarawe and Kazimzumbwi (Tables 3 and 4). In Chanika for example, while the average annual land use change for the built up areas was 18.3 and 44.5 hectares for the period 1975-1995 and 1995-2012, Pugu experienced similar changes of 18.1 to 25.1 hectares per annum in similar periods. Comparatively, Kisarawe and Kazimzumbwi settlements experienced slower land use changes between these periods. In Kisarawe the annual rate of change between 1975-1995 and 1995-2012 was recorded to be 0.9 and 5.1 hectares and for Kazimzumbwi it was insignificant ranging from 2.4 to 3.1 hectares for the same period (Table 4). Results also show that after 1995 agricultural land use for settlements in Dar es Salaam decreased with an rapid increase in the built up land area. This explains the rate at which peri-urban settlements of large cities like Dar es Salaam expand with time. Important to note also is the fact that these land use changes are taking place without formal planning in the form of unplanned settlements. Conversely, agricultural land use increased in Kazimzumbwi by average annual change of 23.2 hectares between 1995 and 2012. The tremendous increase in agricultural land use in Kazimzumbwi is attributed to the fact that this area still exhibits the character of rural settlement where many people from Dar es Salaam and Kisarawe migrate in and open farms for various agricultural activities. 
Table 3. Land use area changes in Chanika and Pugu (1975-2012)

\begin{tabular}{|c|c|c|c|c|c|c|c|c|}
\hline \multirow[t]{3}{*}{ Land Use } & \multicolumn{4}{|c|}{ Chanika } & \multicolumn{4}{|c|}{ Pugu } \\
\hline & \multicolumn{2}{|l|}{ 1975-1995 } & \multicolumn{2}{|c|}{$1995-2012$} & \multirow{2}{*}{$\begin{array}{c}\text { 1975-1995 } \\
\text { Area } \\
\text { change } \\
\text { (ha) }\end{array}$} & \multicolumn{3}{|c|}{ 1995-2012 } \\
\hline & $\begin{array}{c}\text { Area change } \\
\text { (ha) }\end{array}$ & $\begin{array}{l}\text { Land use } \\
\text { change } \\
\text { per year } \\
\text { (ha) }\end{array}$ & $\begin{array}{c}\text { Area } \\
\text { change } \\
\text { (ha) }\end{array}$ & $\begin{array}{c}\text { Land use } \\
\text { change } \\
\text { per year } \\
\text { (ha) }\end{array}$ & & $\begin{array}{l}\text { Land use } \\
\text { change } \\
\text { per year } \\
\text { (ha) }\end{array}$ & $\begin{array}{c}\text { Area } \\
\text { change } \\
\text { (ha) }\end{array}$ & $\begin{array}{c}\text { Land use } \\
\text { change per } \\
\text { year (ha) }\end{array}$ \\
\hline Agricultural & 768.9 & 38.5 & -558 & -32.8 & 91.3 & 4.6 & -223.1 & -13.1 \\
\hline Grazing & $-1,768.40$ & -88.4 & -733.3 & -43.1 & -210.5 & -10.5 & -180.8 & -10.6 \\
\hline Built up area & 365.3 & 18.3 & 756.6 & 44.5 & 161.5 & 8.1 & 326.8 & 19.2 \\
\hline $\begin{array}{l}\text { Residential/ } \\
\text { agricultural }\end{array}$ & 634.1 & 31.7 & 534.8 & 31.5 & -42.3 & -2.1 & 77.1 & 4.5 \\
\hline
\end{tabular}

Table 4. Land use area changes in Kisarawe and Kazimzumbwi (1975-2012)

\begin{tabular}{|c|c|c|c|c|c|c|c|c|}
\hline \multirow[t]{3}{*}{ Land Use } & \multicolumn{4}{|c|}{ Kisarawe } & \multicolumn{4}{|c|}{ Kazimzumbwi } \\
\hline & \multicolumn{2}{|c|}{ 1975-1995 } & \multicolumn{2}{|c|}{$1995-2012$} & \multicolumn{2}{|c|}{ 1975-1995 } & \multicolumn{2}{|c|}{$1995-2012$} \\
\hline & $\begin{array}{c}\text { Area } \\
\text { change } \\
\text { (ha) }\end{array}$ & $\begin{array}{c}\text { Land use } \\
\text { change } \\
\text { per year } \\
\text { (ha) }\end{array}$ & $\begin{array}{c}\text { Area } \\
\text { change } \\
\text { (ha) }\end{array}$ & $\begin{array}{l}\text { Land use } \\
\text { change } \\
\text { per year } \\
\text { (Ha) }\end{array}$ & $\begin{array}{c}\text { Area } \\
\text { change } \\
\text { (ha) }\end{array}$ & $\begin{array}{l}\text { Land use } \\
\text { change } \\
\text { per year } \\
\text { (ha) }\end{array}$ & $\begin{array}{c}\text { Area } \\
\text { change } \\
\text { (ha) }\end{array}$ & $\begin{array}{c}\text { Land use } \\
\text { change per } \\
\text { year (ha) }\end{array}$ \\
\hline Agricultural & 111.2 & 5.6 & -299.7 & -17.6 & 251.2 & 12.6 & 394.4 & 23.2 \\
\hline Grazing & -123.7 & -6.2 & -262.3 & -15.4 & -253.4 & -12.7 & -468.4 & -27.6 \\
\hline Built up area & 17 & 0.9 & 87.3 & 5.1 & 3.9 & 2.4 & 4.3 & 3.1 \\
\hline Residential/ agricultural & -4.6 & -0.2 & 474.8 & 27.9 & -1.8 & -0.1 & 69.7 & 4.1 \\
\hline
\end{tabular}

\section{Effects of Land Use Changes on Ecosystem Services}

The effects emerging from these land use changes on forest ecosystem services ranged from decrease in number of plant and animal species, decrease in water sources from rivers and dams, decrease in honey production and diminishing quality of water.

\subsection{Disappearance of Plant and Animal Species}

Results from socioeconomic data conducted in Chanika, Pugu, Kisarawe and Kazimzumbwi settlements indicated that there was a declining trend of plant species in Pugu and Kazimzumbwi Forest Reserves. It is understood that a number of objective methods such as the Shannon Weaver Index for quantifying biological diversity in conserved and non conserved forests exists. However, in this study a simple and rapid participatory identification method for plant and animal species was adopted and included in the resource mapping in the four settlements. Results showed that plant species decreased from 25 to only 7 between 1970 and 2012. Among these species included; medicinal plants which decreased from 8 to 2. These included; Balanites agyptica (Mtetenasi) which was used to cure blood clotting and providing relief from pain and Trema orientalis (Mpehe) which cures abdominal and chest pain. Others include the four fruit trees namely; Manilkara sulkata (Mcheji), Parinari curatellifolia (Mbula), Dialium holstii (Mtebete) and Saba comorensis (Mbungo) which were reported to have disappeared. It was further reported that animal species have decreased from 18 to 9 . Animal species that used to provide wild meat have decreased from 9 to 3 . The current species which can be seen include; Cepus sp (rabbits), Civetctis civetticus (Fungo) and Thomson ivk (Minokela).

\subsection{Drying of Rivers Water Sources and Decreasing of Water Level in a Dam}

Results from resource mapping revealed that about 7 rivers from Pugu ad Kazimzumbwi which were perennial during the 1975 have dried and remained seasonal. The perennial rivers which have turned seasonal include Msimbazi, Mambizi, Mzumbwi, Kimani, Vikongoro, Nzasa and Nyeburu. Pugu and Kazimzumbwi Forests are the main catchments of these rivers. Also Minaki dam which is located within Pugu forest reserve has experienced drop in water levels from the 1990s. The dam was constructed in 1925 to supply domestic water in Kisarawe Town and Minaki Secondary school. With a capacity of $64000 \mathrm{~m}^{3}$, the dam recorded maximum water 
level of 7m three times in thirty four years (1964, 1978, and 1998). However, in 2010 the water level in the dam reached a dead storage (Photo 1). The drop of Minaki dam water level to a dead storage level necessitated Kisarawe District to dredge the dam and extent its depth to $1.5 \mathrm{~m}$ below the dead storage level in order to provide source of water supply for Kisarawe District and Minaki Secondary school.

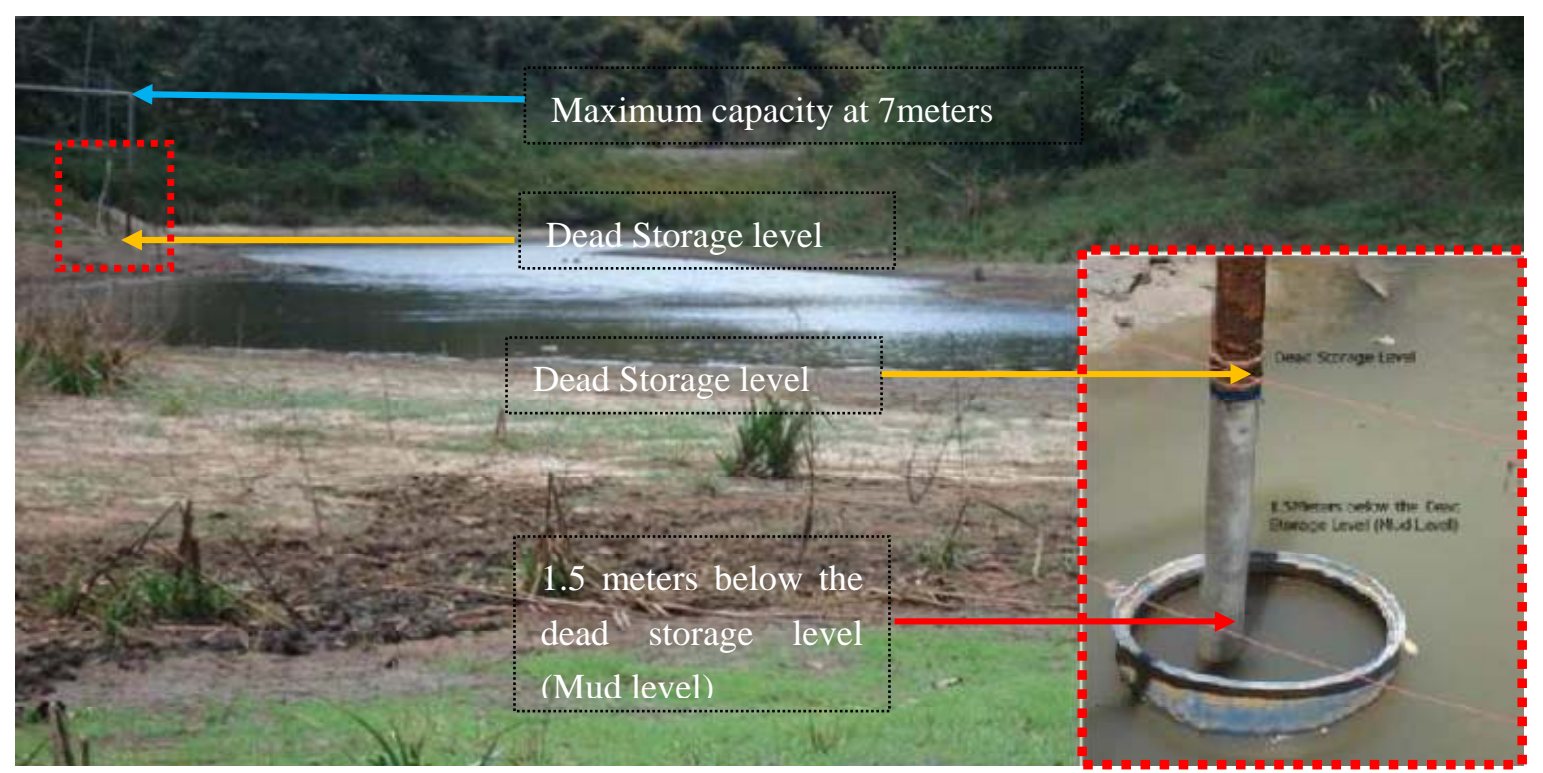

Photo 1. Dried parts of Minaki dam (large photo) and water levels below the dead storage (smaller photo inserted right) within Minaki Dam

Source: Kisarawe District Council, September 2012.

The drop of water level has been influenced among other by increased human activities surrounding and within the forest catchments. As result, the quality of water has been affected. Records of water quality from the dam showed an increase in concentration of Manganese and iron from 1964 to 2008 (Table 5). Increased human activities in the surrounding of the forests and within the forest reserve have contributed to declining water levels and deterioration of water quality in the dam.

Table 5. Trends of chemical contents in Minaki water source

\begin{tabular}{lccc}
\hline Chemicals & 1964 & 1990 & 2008 \\
\hline Iron $(\mathrm{Fe})$ & $0.21 \mathrm{mg} / \mathrm{l}$ & $1.82 \mathrm{mg} / \mathrm{l}$ & $3.04 \mathrm{mg} / \mathrm{l}$ \\
Manganese (Mn) & $0.40 \mathrm{mg} / \mathrm{l}$ & $3.73 \mathrm{mg} / \mathrm{l}$ & $5.22 \mathrm{mg} / \mathrm{l}$ \\
\hline
\end{tabular}

\subsection{Decrease in Honey Production and Disappearance of Mushrooms}

Honey production was introduced by the Kisarawe District Council since 2005. It was reported by the Kisarawe District Beekeeping Officer that a total of 25 people within the study area (mostly from Kimani sub ward in Kisarawe) were engaged in honey production as one of the livelihood activities. However, trend in honey production has shown diminishing trends with time. While at the beginning of the project production of honey and wax stood at 68 kilograms of honey and 5 kilograms of wax in 2005/06, there was neither honey nor wax that was being produced in the year 2011/2012 (Table 6). Mushrooms also disappeared since early 1990s. Resource mapping in the four settlements indicated that mushroom harvesting was no longer a popular activity and none of the interviewed households responded to use mushrooms as food resources. Resource mapping also showed that mushrooms had become a rare ecosystem service period 1995. The disappearance of mushrooms, honey and wax production is linked to clearance of the Miombo tree species which usually support growth of mushrooms and suspension of bee hives. Being one of the hard wood species, the Miombo are also a good resource for charcoal making that constitute one of the livelihood activities of many people in these settlements. 
Table 6. Honey and wax production in Kisarawe (2005/06 to 2011/12)

\begin{tabular}{lccccccc}
\hline Production $/ \mathrm{Kg}$ & $2005 / 06$ & $2006 / 07$ & $2007 / 08$ & $2008 / 09$ & $2009 / 10$ & $2010 / 11$ & $2011 / 12$ \\
\hline Honey (Kg) & 68 & 134 & 84 & 56 & 45 & 31 & 0 \\
Wax (Kg) & 5 & 9 & 7 & 4 & 2 & 0 & 0 \\
\hline
\end{tabular}

\section{Institutional Responses and Strategies for Addressing Coastal Forest Ecosystem Services Degradation}

The National wide strategies for addressing issues of forest ecosystem degradation have mainly been through enacting legal framework to guide forest conservation. These include The Forest Act No 14, of 2002, Environmental Management Act 2004, The National, Land Policy of 1997 and The Urban Planning Act No.8 of 2007. All these policies and legislations acknowledge the need for protection of nature and scenic areas of national or international significance and to maintain and enhance bio-diversity and genetic resources known as a nature forest reserve. Key informants indicated that surveying of all villages in Kisarawe that surround the forests which led to approval of survey plan referenced Kis/Dist/Gen No. 44950 in 2007 was another strategy to address the conflicting land uses and forest conservation initiatives. Demolition of over 500 residential developments in Nzasa and Kimwani settlements of Chanika in years 2008 and 2010 that squatted in Kazimzumbwi Forest was another response from the government. The government also issued a notice to restrict any land subdivision in the forests in 2010. Awareness campaigns and environmental education provided at ward and village levels about protection of the forests through environmental committees and education provision on alternative income sources such as modern bee keeping and tree plantation where trees were provided for free to the people. Tree plantation campaign was conducted in the forest reserves where about 100,500 trees both foreign and exotic species were planted between 2009 and 2011.

Conservation efforts by conservation organizations including CARE, Wildlife Conservation Society of Tanzania (WCST) and MJUMITA with the involvement of communities were initiated and implemented between 1985 and 1995. However, the conservation initiative, although contributed to improvement of forest coverage, were unsustainable due to lack of legally recognized community institutions for the management of the forest reserves.

Conservation efforts are largely hampered by households who illegally engaged harvesting forest related products such as charcoal. Charcoal products were reported to provide higher incomes compared to household engaged in agriculture (Kahyarara, Mbowe and Kimweri 2002). ). Other limiting factors towards forest conservation have been reported to include corruption and centralization of forest management. Some of the forest guards were reported to collect kickbacks (bribes) from unlicensed charcoal from Chanika and Kazimzumbwi. Amidst limited controls from the government, this malpractice perpetuates deforestation and degradation of the forest reserves. Although several court cases have been filed against illegal charcoal harvesting from 96 to 156 cases between 2008 and 2011, illegal charcoal harvesting has continued unabated. Members of Village Environmental Committees at grass root level complained over marginalization by central government authorities in managing Pugu and Kazimzumbwi Forest Reserves.

\section{Discussion}

The analysis presented show declining trends in availability of ecosystem services. The most evident changes are manifest in dramatic decrease in water levels and drying of potential sources of water such as rivers and dams. This situation is serious because it directly impacts on the survival of organisms that are entirely dependent on these services. Studies conducted in Pugu and Kazimzumbwi Forest Reserves such as Malugu (2007), Frontier Tanzania (2004), Mialla and Kijazi (2003) under Misitu Yetu Project converge with findings of this project on declining trend of ecosystem services over time.

Land uses under built up areas which include residential commercial, industrial and institutional settlements, and infrastructures consistently increased over the period of 37 years. Agriculture land use increased in the first half of the analysis period while in the second half it decreased. Grazing and open land uses consistently declined throughout the period of analysis. The decrease of agricultural and grazing land uses was associated with increase in built up areas. These changes in land uses contributed to decline in ecosystem services due to high pressure on provisioning services from the population of the surrounding areas. The decline of these services is linked to two major factors. Firstly is the rapid population increase particularly in peri-urban settlements of Dar es Salaam which is triggered by rural-urban and intra-urban migrations. Population increase has culminated into increased demand for residential land use and livelihood activities including agriculture. Utilization of forest products exacerbates pressure on the two forest reserves and therefore contributes to significant decline in 
ecosystem services. Secondly is deforestation which also draws its link to increased human activities manifested in changes of land uses. Results from Kashaigili et al. (2013) that investigated forest cover changes for the two forest reserves for the period between 1980 and 2010 indicates that closed forest decreased from 2106.6 hectares (87.2 percent) in 1980 to 1386 hectares ( 57.4 percent) in 2010. On the contrary, open forest increased from 110.4 hectares in 1980 to 490.2 hectares in 2010 . These statistics serves to indicate that the intensification of human activities manifested in land use changes surrounding the two forest reserves equally affects the forest cover with subsequent effects on the decline of ecosystem services. Important also to note is the fact that development in these settlements has been taking place with limited guidance from the local authorities. Informal settlements development is a characteristic feature in most of these peri-urban settlements. Although a clear line between land use changes and ecosystem services cannot be explicitly drawn, it is worth noting that land use changes especially the unguided rapid expansion of settlements seems to play a key contribution in the decline of ecosystem services from the two forest reserves.

\section{Conclusions and Recommendations}

Results from this study have shown that there is a significant change in land uses for settlements surrounding Pugu and Kazimzumbwi Forests from 1970s to 2012. Major changes are seen in the built up and agricultural land uses where in Dar es Salaam; the built up area is increasing with the decrease in agricultural land use. In Kisarawe, agricultural land use is increasing significantly concurrent with the increase in the built up area. The key driver of land uses changes is the rapid population increase which culminates into rapid growth of peri-urban settlements. Remarkable changes started in the 1990s. Results further show that there is a declining trend of ecosystem services emanating from Pugu and Kazimzumbwi forest reserves which is manifested in decreasing medicinal plant species, decrease in quantity and quality of water and decrease in honey, wax and mushroom products. Increased and unplanned human activities have significantly contributed to the decrease in forest cover and declining ecosystem services from Pugu and Kazimzumbwi Forest Reserves. Despite the several attempts to reconcile the conflicting land uses including the demolition of houses, little achievements have been realized to conserve the forest reserves.

On the basis of these observations the following recommendations are being raised:

- There is a need to prepare an integrated participatory land use plan that oversees future population growth, land use dynamics in settlements that surround forest reserves, protect biological hotspots and ensure that the planning process brings together various actors and stakeholders. For unplanned settlements that are increasing expanding and consolidating, an upgrading plan should be developed thereby delineating clear boundaries between built up areas and forest reserves.

- In order to restore ecosystem services that used to ensue from these forests, the participation of many stakeholders in managing and conserving these forests is crucial. There is therefore a need for decentralized management involving the local government committees such as the village environmental committees and NGOs that have been coordinating people's initiatives in these areas.

\section{Acknowledgement}

This research was supported by a NORAD funded research programme in Tanzania namely; Climate Change Impacts, Adaptation and Mitigation (CCIAM). It was implemented at Ardhi University under the research project called; Analysis of the Impacts of Urban Land Use and Climate Change on Coastal Forest Ecosystem and Management (AIULUCC, 2009-2013). It drew members from Ardhi University, Sokoine University of Agriculture, University of Dar es Salaam and Tanzania Meteorological Agency. The authors also acknowledge all those who provided comments and suggestions during the CCIAM writer's workshop in November 2013 when this draft paper was presented.

\section{References}

AIULUCC. (2013). Analysis of the Impacts of Urban Land Use and Climate Change on Coastal Forest Ecosystem and Management, Project Progress Reports for the period 2009-2013, CCIAM Prorgamme, Ardhi University, Dar es Salaam, Tanzania.

Briggs, J., \& Mwamfupe, D. (2000). The changing Nature of the Peri-Urban Zone in Africa: Evidence from Dar es Salaam, Tanzania. Scottish Geographical Journal, 115(4), 269-282. http://dx.doi.org/10.1080/00369229918737070

Burgess, N., \& Dickinson, A. (1993). Coastal Forest Research Programme, Site Description and Evaluation: Kazimzumbwi Forest, Kisarawe District, Tanzania: The Society for Environmental Exploration and University of Dar es Salaam: Thames House, London. Retrieved February 21, 2013, from 
http://coastalforests.tfcg.org/pubs/Frontierpercent20Kazimzumbwipercent20Forest,percent20Kisaraweperce nt20Districtpercent201993.pdf

Butungo, S. (2013). Effects of Urban and Peri Urban Land Use Changes on Forest Ecosystem Services: The Case of Pugu and Kazimzumbwi Forest Reserves in Dar es Salaam and Kisarawe, Tanzania, Unpublished Master Thesis, Ardhi University, Dar es Salaam, Tanzania.

CARE T. (2001). Socio Economic Survey of Pugu and Kazimzumbwi Forest Reserves - Misitu Yetu Project, Unpublished Internal Report 2001 p.58.

Douglas, I. (2006). Peri-urban Ecosystems and Societies Transitional Zones and Contrasting Values, In Peri-Urban Interface: Approaches to Sustainable Natural and Human Resource Use. In D. McGregor, D. Simon, \& D. Thompson (Eds.), pp. 18-29, Earthscan Publications Ltd. London, UK.

Frontier, T. (2004). Kazimzumbwi Forest Reserve: A Biodiversity Survey. In D. Fanning, \& K. Howell (Eds.), Frontier Tanzania Research Report 110.

Kahyarara, G., Mbowe, W., \& Kimweri, O. (2002). Poverty and Deforestation around the Gazetted Forests of the Coastal Belt of Tanzania, Research on Poverty Alleviation, Research Report No: 02.3, REPOA, Dar es Salaam.

Kashaigili, J., Mdemu, M., Nduganda, A., \& Mbilinyi, P. (2013). Integrated Assessment of Forest Cover Change and Above Ground Carbon Stock Changes in Pugu and Kazimzumbwi Forest Reserves in Kisarawe District, Tanzania. Journal of Advances in Remote Sensing, 2, 1-9. http://dx.doi.org/10.4236/ars.2013.21001

Lambin, E., Geist, H., \& Lepers, E. (2003). Dynamics of Land-Use and Land-Cover Change in Tropical Regions. Department of Geography, University of Louvaine-Belgium. Retrieved August 22, 2012, from http://www.annualrewiews.org

Lupala, J. (2002). Urban Types in Rapidly Urbanizing Cities: Analysis of Formal and Informal Settlements in Dar es Salaam, Tanzania, Royal Institute of Technology, KTH, Stockholm, Sweden.

Malugu, E. (2007). Resource-Use Conflicts and Management Challenges for Pugu and Kazimzumbwi Forest reserves in Kisarawe and Ilala Districts, Tanzania. Retrieved February 21, 2012, from http://www.puguhills.com/forests/kazimzumbwi-forest.htm

Mialla, Y. S., \& Kijazi, M. S. (2003). Demarcation of Village Forest Management Areas in Designated Forest Reserves, Misitu Yetu Project, A Partnership between Wildlife Conservation Society of Tanzania, Tanzania Forest Conservation Group and CARE- Tanzania, MYP Assistance, Morogoro and Tanga, Tanzania.

Monga, E., \& Gwegime, J. (2011). Dar es Salaam is Being Stripped of its Green Belt: We Need Action Now, The Arc Journal Tanzania Forest Conservation Group. Biannual Newsletter Issue No. 26, December 2011.

Nasi, R., \& Wunder, S. J. (2002). Forest Ecosystem Services: Can They Pay Our Way Out Of Deforestation? GEF, Center for International Forestry Research, Jakarta, Indonesia and Tropical Agricultural Research and Higher Education Center, CATIE 7170, Turrialba, Costa Rica.

United Republic of Tanzania (URT). (2002). Population and Housing Census General Report: Village and Street Statistics, Age and Sex Distribution Vol VII: Central Census Office, National Bureau of Statistics, Government Printers, Dar es Salam.

United Republic of Tanzania (URT). (2013). Population and Housing Census General Report, Village and Street Statistics, Age and Sex Distribution Vol VII: Central Census Office, National Bureau of Statistics, Government Printers, Dar es Salam.

United Republic of Tanzania (URT). (1967-2002). Population Census Reports; Statistics for Enumerical Areas: National Bureau of Statistics, Ministry of Economic Afairs and Planning, Government Printers, Dar es Salaam.

\section{Copyrights}

Copyright for this article is retained by the author(s), with first publication rights granted to the journal.

This is an open-access article distributed under the terms and conditions of the Creative Commons Attribution license (http://creativecommons.org/licenses/by/3.0/). 